\title{
CARBOHYDRATE INTAKE, GLYCEMIC INDEX, GLYCEMIC LOAD AND RISK OF GASTRIC CANCER
}

\author{
Konstansa Lazarević ${ }^{1}$, Aleksandar Nagorniं ${ }^{2,3}$, Miroslav Jeremic ${ }^{3,4}$ \\ ${ }^{1}$ Public Health Institute Niš, Serbia \\ ${ }^{2}$ Gastroenterology and hepatology Clinic, Clinical Center Niš, Serbia \\ ${ }^{3}$ School of Medicine, University of Niš, Serbia \\ ${ }^{4}$ Surgical Clinic, Clinical Center Niš, Serbia
}

\begin{abstract}
SUMMARY
The aim of this study was to examine relationship between dietary carbohydrate, glycemic index, glycemic load and gastric cancer risk. This hospital based case-control study was conducted in Niš (Serbia) between 2005 and 2006. Subjects ( $\mathrm{n=102)}$ with histologically confirmed gastric cancer and controls $(n=204)$ selected from non-cancer patients were interviewed. The structured questionnaire included information on socio-demographic and lifestyle habits. Data from dietary habits were based on Food Frequency Questionnaire (FFQ). We found reductions in gastric cancer risk for diets high in carbohydrate (OR for highest versus the lowest tertile $=0.07,95 \% \mathrm{Cl}: 0.02-0.23$ ) and mono- and disaccharides (OR=0.03, $95 \% \mathrm{Cl}: 0.01-0.09)$ and increased risk (OR=4.13, 95\% Cl:1.73-9.86) for high polysaccharide intake. Total carbohydrate intake $(\mathrm{OR}=0.17,95 \%$ $\mathrm{Cl}: 0.04-0.66)$ and mono- and disaccharides intake (OR=0.06, 95\% Cl: 0.02-0.20) was associated with a reduction in gastric cancer risk, while polysaccharide intake was associated with an increased risk (OR=4.85, 95\% Cl: 1.67-14.09) for the diffuse type only. In both histological subtypes, there was not significant association between glycemic index, glycemic load and the risk of gastric cancer. Our results suggest that increased intake of foods rich in carbohydrate, particularly mono- and disaccharides, as well as reduced consumption of food rich in polysaccharides, may lower the risk of diffuse type of gastric cancer. Our data do not support association between glycemic index, glycemic load and the risk of gastric cancer.
\end{abstract}

Key words: diet, carbohydrate, glycemic index, glycemic load, gastric cancer

Address for correspondence: K. Lazarević, Public Health Institute, Dr Z Djindjica 50,18000 Niš, Serbia. E-mail: koni33@hotmail.com

\section{INTRODUCTION}

Worldwide, gastric cancer ranks fourth in incidence and is the second leading cause of death from cancer (1). This relatively high death rate is due to the fact that gastric cancer is rarely diagnosed early and when it is detected, the cancer is usually surgically hard to manage (2).

Dietary factors play a major role in the etiology of gastric cancer (3). Diets high in carbohydrate have been hypothesized to increase cancer risk by increasing insulin load and the risk of hyperinsulinemia. Hyperinsulinemia leads to increased insulinlike growth factors (IGF) bioavailability. The significant positive association between levels of serum binding protein IFG-I, IGF-II, and IGFBP-3 and gastric cancer risk have been found in 3 studies $(4,5,6)$.

Postprandial and average insulin concentrations are directly influenced by the type, amount, and rate of digestion of dietary carbohydrates (7). Glycemic index and glycemic load are measures that allow the carbohydrate content of individual foods to be classified according to their postprandial glycemic effects.

The aim of this case control study was to examine the role of dietary carbohydrate and the glycemic index or the glycemic load in the etiology of gastric cancer.

\section{MATERIALS AND METHODS}

The present study is a hospital based case-control study conducted between January 2005 and December 2006 in Niš (Serbia). Briefly, 102 patients (58 males, 44 females: median age 67 years, range $45-85$ y) with histologically confirmed gastric cancer (gastric adenocarcinoma) were admitted to the Surgery Clinic of University Hospital in Niš (Serbia). These cases represented approximately $70 \%$ of those reported to the National Cancer registry in the same period in Nišava District. The confirmed cases were defined by Laurén classification (8) into intestinal ( $n=29)$, diffuse $(n=70)$ and unclassified $(n=3)$.

Age $( \pm 3$ y) -, gender-, and residence-matched controls were 204 subjects (116 males, 88 females: median age 66.5 years, range 45-85) residing in the same geographical area and admitted to the same hospital as cases for acute non-neoplastic diseases.

All interviews were conducted by a physician in a hospital setting. The structured questionnaire included personal information (name, date and place of birth, gender, education and life-style habits (smoking habits, physical activity), personal medical history and family history of cancer. A food-frequency questionnaire (FFQ) was used to assess subjects' habitual diet, including information on weekly frequency of consumption of 
Table 1. Comparison of characteristics for education, life style, dietary habits and medical history among study subjects ${ }^{1}$

\begin{tabular}{|c|c|c|c|c|}
\hline Variable & Group & $\begin{array}{l}\text { Cases } \\
(n=102)\end{array}$ & $\begin{array}{l}\text { Controls } \\
(n=204)\end{array}$ & $\mathrm{OR}^{2}(95 \% \mathrm{Cl})^{3}$ \\
\hline $\begin{array}{l}\text { Education } \\
\text { (school attendance in years) }\end{array}$ & $\begin{array}{l}0-9 y \\
>9 y\end{array}$ & $\begin{array}{l}59 \\
43\end{array}$ & $\begin{array}{l}101 \\
103\end{array}$ & $1.40(0.84-2.33)$ \\
\hline Physical activity & $\begin{array}{c}\text { yes } \\
\text { no }\end{array}$ & $\begin{array}{l}38 \\
64 \\
\end{array}$ & $\begin{array}{c}71 \\
133\end{array}$ & $1.11(0.66-1.88)$ \\
\hline Tobacco smoking & $\begin{array}{c}\text { yes } \\
\text { no }\end{array}$ & $\begin{array}{l}38 \\
64 \\
\end{array}$ & $\begin{array}{c}45 \\
159 \\
\end{array}$ & $2.10(1.61-3.65)^{*}$ \\
\hline Alcohol drinking & $\begin{array}{l}\text { ever drinkers } \\
\text { non-drinkers }\end{array}$ & $\begin{array}{l}70 \\
32\end{array}$ & $\begin{array}{c}84 \\
120\end{array}$ & $3.13(1.84-5.34)^{*}$ \\
\hline Irregular meals & $\begin{array}{l}\text { yes } \\
\text { no }\end{array}$ & $\begin{array}{l}78 \\
24\end{array}$ & $\begin{array}{c}98 \\
106\end{array}$ & $3.45(1.96-6.10)^{*}$ \\
\hline Overeating at every meal & $\begin{array}{c}\text { yes } \\
\text { no }\end{array}$ & $\begin{array}{l}38 \\
64\end{array}$ & $\begin{array}{c}33 \\
171\end{array}$ & $3.08(1.72-5.52)^{\star}$ \\
\hline Rapid eating & $\begin{array}{c}\text { yes } \\
\text { no }\end{array}$ & $\begin{array}{l}67 \\
35\end{array}$ & $\begin{array}{c}99 \\
103\end{array}$ & $1.99(1.18-3.36)^{*}$ \\
\hline History of cancer in the first degree & $\begin{array}{c}\text { yes } \\
\text { no }\end{array}$ & $\begin{array}{l}41 \\
61\end{array}$ & $\begin{array}{c}44 \\
160\end{array}$ & $2.44(1.41-4.24)^{*}$ \\
\hline Family history of diabetes & $\begin{array}{l}\text { yes } \\
\text { no }\end{array}$ & $\begin{array}{l}12 \\
90\end{array}$ & $\begin{array}{c}17 \\
187\end{array}$ & $1.47(0.63-3.41)$ \\
\hline
\end{tabular}

${ }^{1}$ Univariate logistic regression analysis

2Odds ratio

${ }^{3}$ Confidence interval

${ }^{*} p<0.05$

specific foods in course of 1 year prior to cancer diagnosis or hospital admission (for controls). The FFQ included 98 foods, food groups or recipes. All cases and controls in this study were recruited on a voluntary basis.

Values of glycemic index were obtained from international tables (9), and expressed as a percentage of the glycemic response elicited using glucose as a standard food.

For each subject, average daily glycemic index was calculated by summing the products of the carbohydrate content per serving, for each food or recipe, multiplied by the number of servings per week, and multiplied by its glycemic index, all divided by the total amount of available daily carbohydrate intake. A score of the daily average glycemic load was computed as the glycemic index but without dividing by the total amount of carbohydrates.

Univariate logistic regression was performed to calculate risk for gastric cancer for education, physical activity, meals regularity, rapid eating, overeating at each meal, history of diabetes and history of cancer in the first degree.

Odds ratio (OR) and the corresponding 95\% confidence intervals (CI) also were computed by tertile of daily carbohydrate intake and glycemic index and glycemic load score, using multivariate logistic regression models, controlling for age (continuous), sex (male, female), education ( $<9 \mathrm{y},>9 \mathrm{y}$ ), physical activity (yes, no), total energy intake (continuous), meals regularity, rapid eating (yes, no), overeating at each meal (yes, no) and history of cancer in the first degree (yes, no).

Backward method was performed. Only important controlling variables $(\mathrm{p}<0.1)$ were included in final models. Tested variables (total carbohydrate, mono- and disaccharides, polysaccharides, glycemic index and glycemic load) were considered as unconditional.
The lowest level of consumption was used as the reference category in the estimation, and $p$-value of less than 0.05 was considered statistically significant. Analyses were carried out by the SPSS version10.0 software.

\section{RESULTS}

In our study cigarette smoking, alcohol consumption, irregular meals, rapid eating, overeating at every meal and family history of cancer in first-degree relatives were all significant risk factors for gastric cancer (Table 1).

Compared with the lowest level of intake, a positive association with gastric cancer was found for the highest level of total carbohydrate intake (OR=0.07, 95\% CI: 0.02-0.23) and mono-and disaccharides (OR=0.03, 95\% CI: 0.01-0.09). For polysaccharides, subjects with the highest intake had a significantly increased risk of gastric cancer (OR=4.31, 95\%CI: 1.73-9.86). No associations were observed for glycemic index, glycemic load and the risk of gastric cancer (Table 2).

Logistic regression showed (Table 3) that higher dietary carbohydrate intake (OR=0.17, 95\% CI: 0.04-0.66) particularly mono- and disaccharides (OR=0.06, 95\% CI: 0.02-0.20) was associated with a reduction in gastric cancer risk for the diffuse type only. Polysaccharide intake (OR=4.85, 95\% CI: 1.67-14.09) was associated with an increased risk of gastric cancer of diffuse histological subtype. There was no evidence of increased risk for gastric cancer associated with high glycemic load or glycemic index in both - intestinal and diffuse histological subtype (Table 3) 
Table 2. Odds ratios of gastric cancer by tertile of daily carbohydrate intake, glycemic index and glycemic load ${ }^{1}(n=102)$

\begin{tabular}{|l|c|c|c|}
\hline \multirow{2}{*}{ Variable } & II Tertile & III Tertile & \multirow{2}{*}{$\mathrm{p}$} \\
\cline { 2 - 4 } & $\mathrm{OR}^{2}(\mathrm{Cl} 95 \%)^{3}$ & OR (Cl 95\%) & $0.000^{*}$ \\
\hline Total carbohydrate & $0.40(0.19-0.88)$ & $0.07(0.02-0.23)$ & $0.000^{*}$ \\
\hline Mono- and disaccharides & $0.26(0.11-0.59)$ & $0.03(0.01-0.09)$ & $0.001^{*}$ \\
\hline Glycemic index & $2.05(0.89-4.70)$ & $4.13(1.73-9.86)$ & 0.393 \\
\hline Glycemic load & $1.14(0.47-2.76)$ & $0.39(0.14-1.15)$ & 0.652 \\
\hline
\end{tabular}

${ }^{1}$ Multivariate models included: age, sex, residence, education, physical activity, total energy intake, meals regularity, rapid eating, overeating at each meal, and history of cancer in the first degree

${ }^{2}$ Odds ratio

${ }^{3}$ Confidence interval

${ }^{*} \mathrm{p}<0.05$

Table 3. Odds ratios of intestinal and diffuse type of gastric cancer by tertile of daily carbohydrate intake, glycemic index and glycemic load ${ }^{1}$

\begin{tabular}{|c|c|c|c|c|}
\hline \multirow{2}{*}{ Variable } & \multicolumn{2}{|c|}{ Intestinal type $(n=29)$} & \multicolumn{2}{|c|}{ Diffuse type $(n=70)$} \\
\hline & $\mathrm{OR}^{2}(\mathrm{Cl} 95 \%)^{3}$ & $p$ & OR (Cl 95\%) & $p$ \\
\hline $\begin{array}{l}\text { Total carbohydrate } \\
\text { II tertile } \\
\text { III tertile }\end{array}$ & $\begin{array}{l}6.89(1.28-22.94) \\
7.02(0.95-31.98)\end{array}$ & $\begin{array}{l}0.032^{\star} \\
0.056\end{array}$ & $\begin{array}{l}4.67(0.18-1.20) \\
0.17(0.04-0.66)\end{array}$ & $\begin{array}{l}0.113 \\
0.011^{*}\end{array}$ \\
\hline $\begin{array}{l}\text { Mono-and disaccharides } \\
\text { II tertile } \\
\text { III tertile }\end{array}$ & $\begin{array}{l}0.30(0.06-1.45) \\
0.18(0.11-1.25)\end{array}$ & $\begin{array}{l}0.135 \\
0.202\end{array}$ & $\begin{array}{l}0.22(0.86-0.59) \\
0.06(0.02-0.20)\end{array}$ & $\begin{array}{l}0.002^{*} \\
0.000^{*}\end{array}$ \\
\hline $\begin{array}{l}\text { Polysaccharides } \\
\text { II tertile } \\
\text { III tertile }\end{array}$ & $\begin{array}{l}2.95(0.55-15.93) \\
4.10(0.97-25.26)\end{array}$ & $\begin{array}{l}0.208 \\
0.068\end{array}$ & $\begin{array}{c}1.70(0.62-4.66) \\
4.85(1.67-14.09)\end{array}$ & $\begin{array}{l}0.305 \\
0.004^{*}\end{array}$ \\
\hline $\begin{array}{l}\text { Glycemic index } \\
\text { II tertile } \\
\text { III tertile }\end{array}$ & $\begin{array}{l}1.63(0.32-8.43) \\
1.19(0.02-1.66)\end{array}$ & $\begin{array}{l}0.558 \\
0.134\end{array}$ & $\begin{array}{l}1.08(0.40-2.89) \\
0.37(0.12-1.20)\end{array}$ & $\begin{array}{l}0.877 \\
0.097\end{array}$ \\
\hline $\begin{array}{l}\text { Glycemic load } \\
\text { II tertile } \\
\text { III tertile }\end{array}$ & $\begin{array}{c}1.76(0.32-9.57) \\
2.64(0.32-22.32)\end{array}$ & $\begin{array}{l}0.513 \\
0.369\end{array}$ & $\begin{array}{l}0.73(0.28-1.89) \\
0.94(0.29-3.30)\end{array}$ & $\begin{array}{l}0.517 \\
0.912\end{array}$ \\
\hline
\end{tabular}

${ }^{1}$ Multivariate models included: age, sex, residence, education, physical activity, total energy intake, meals regularity, rapid eating, overeating at each meal, and history of cancer in the first degree

${ }^{2}$ Odds ratio

${ }^{3}$ Confidence interval

${ }^{*} \mathrm{p}<0.05$

\section{DISCUSSION}

In our study, high intake of carbohydrates was associated with a statistically significant reduction in the risk of gastric cancer. Most previous studies did not observe association between dietary carbohydrate intake and gastric cancer (10-14) whereas other studies have suggested positive (15-18) or inverse (19, 20, 21) associations.

One possible explanation of these results is that dietary and non-dietary risk factors were not adequately controlled. In our study, many known but also suspected risk factors for gastric cancer including physical activity, irregular meals, speed eating, overeating at each meals were scrutinized. Physical activity may reduce cancer risk by reducing circulating concentrations of insulin and insulin-like growth factors (22). Regular eating also has beneficial effects on postprandial insulin profiles (23). The available scientific evidence indicates that increased risks for gastric cancer were associated with irregular meals $(24,25,26)$, rapid eating (24, 25, 26) and binge eating (26).

Also, carbohydrate quality rather than quantity of intake may be important in gastric cancer risk.

Investigators in Belgium (27) and France (28) have reported positive association with dietary intake of mono- and disaccharides and risk of gastric cancer. In a study conducted in USA, it was observed that dietary carbohydrate was protective factor for diffuse type of gastric cancer (29). In our study gastric cancer risk was decreased with diets rich in mono- and disaccharides, but showed increase in case of high intake of polysaccharides - only for diffuse histological subtype.

Worldwide the gastric cancer incidence rates have been declining (1) but incidence of diffuse histological subtype has 
been increasing (30). This is the reason why the knowledge of risk factors for the development of this type of gastric carcinoma is of outmost importance.

The relation of glycemic index and glycemic load to gastric cancer risk was investigated in only two large prospective cohorts (Italy and Sweden).

In the study conducted in Italy (31) diets with high glycemic load were associated with increased risk of gastric cancer. Significant associations between carbohydrate intake, glycemic index and glycemic load with gastric cancer risk were not observed in the population based Swedish Mammography Cohort (10). One of the possible explanations for inconsistent results may be the different type of carbohydrates used in the two different population (Italian and Sweden), as well as methodological biases. Also the genotype for insulin resistance may differ between ethnic groups (32). Glycemicindex and glycemic load values presented in International table were determined for only a limited number of foods (9).

In our investigation, when analyzed separately by histological subtype, glycemic index and glycemic load were not associated with increased risk of gastric cancer.

Our study had certain limitations. This study had a relatively small sample size. The small sample size (especially for persons with intestinal type of gastric cancer) and many confounding factors in study may have somewhat limited our ability to estimate the association more precisely. We did not obtain information on Helicobacter pylori infection. $H$. pylori infection is associated with an increased risk of gastric cancer $(33,34)$.

Our results do not support an association between diets high in carbohydrate, glycemic index or glycemic load and gastric cancer. Increased intake of foods rich in carbohydrate particularly mono- and disaccharides as well as reduced consumption of food rich in polysaccharide may lower the risk of diffuse type of gastric cancer. To make a clear conclusion regarding the association between glycemic index and glycemic load and gastric cancer risk intervention or experimental study is needed.

\section{REFERENCES}

1. Parkin DM, Bray F, Ferlay J, Pisani P. Global cancer statistics, 2002. CA Cancer J Clin. 2005 Mar-Apr;55(2):74-108.

2. Maconi G, Manes G, Porro GB. Role of symptoms in diagnosis and outcome of gastric cancer. World J Gastroenterol. 2008 Feb 28;14(8):1149-55.

3. World Cancer Research Fund, American Institute for Cancer Research. Food, nutrition, physical activity and the prevention of cancer: a global perspective. Washington DC: AICR; 2007.

4. Zhang ZW, Newcomb PV, Moorghen M, Gupta J, Feakins R, Savage $\mathrm{P}$, et al. Insulin-like growth factor binding protein-3: relationship to the development of gastric pre-malignancy and gastric adenocarcinoma (United Kingdom). Cancer Causes Control. 2004 Mar;15(2):211-8.

5. Franciosi CM, Piacentini MG, Conti M, Romano F, Musco F, Caprotti $\mathrm{R}$, et al. IGF-1 and IGF-1BP3 in gastric adenocarcinoma. Preliminary study. Hepatogastroenterology. 2003 Jan-Feb;50(49):297-300.

6. Zhao MD, Hu XM, Sun DJ, Zhang Q, Zhang YH, Meng W. Expression of some tumor associated factors in human carcinogenesis and development of gastric carcinoma. World J Gastroenterol. 2005 Jun 7;11(21):3217-21.

7. Wolever TM, Bolognesi C. Source and amount of carbohydrate affect postprandial glucose and insulin in normal subjects. J Nutr. 1996 Nov;126(11):2798-806.

8. Laurén P. The two histological main types of gastric carcinoma: diffuse and so-called intestinal type carcinoma. An attempt at a histo-clinical classification. Acta Pathol Microbiol Scand. 1965;64:31-49.

9. Foster-Powell K, Holt SH, Brand-Miller JC. International table of glycemic index and glycemic load values: 2002. Am J Clin Nutr. 2002 Jul;76(1):5-56.
10. Mayne ST, Risch HA, Dubrow R, Chow WH, Gammon MD, Vaughan TL, et al. Nutrient intake and risk of subtypes of esophageal and gastric cancer. Cancer Epidemiol Biomarkers Prev. 2001 Oct;10(10):1055-62.

11. Palli D, Russo A, Decarli A. Dietary patterns, nutrient intake and gastric cancer in a high-risk area of Italy. Cancer Causes Control. 2001 Feb;12(2):163-72.

12. Nomura AM, Hankin JH, Kolonel LN, Wilkens LR, Goodman MT, Stemmermann GN. Case-control study of diet and other risk factors for gastric cancer in Hawaii (United States). Cancer Causes Control. 2003 Aug;14(6):547-58.

13. Larsson SC, Bergkvist L, Wolk A. Glycemic load, glycemic index and carbohydrate intake in relation to risk of stomach cancer: a prospective study. Int J Cancer. 2006 Jun 15;118(12):3167-9.

14. De Stefani E, Boffetta P, Deneo-Pellegrini H, Mendilaharsu M, Carzoglio JC, Ronco A. Carbohydrates and risk of stomach cancer in Uruguay. Int J Cancer. 1999 Aug 12;82(4):618-21.

15. Azevedo LF, Salgueiro LF, Claro R, Teixeira-Pinto A, Costa-Pereira A. Diet and gastric cancer in Portugal-a multivariate model. Eur J Cancer Prev. 1999 Feb;8(1):41-8.

16. Lissowska J, Gail MH, Pee D, Groves FD, Sobin LH, NasierowskaGuttmejer A, et al. Diet and stomach cancer risk in Warsaw, Poland. Nutr Cancer. 2004;48(2):149-59.

17. Jedrychowski W, Popiela T, Steindorf K, Tobiasz-Adamczyk B, Kulig J, Penar A, et al. Nutrient intake patterns in gastric and colorectal cancers. Int J Occup Med Environ Health. 2001;14(4):391-5.

18. Muñoz N, Plummer M, Vivas J, Moreno V, De Sanjosé S, Lopez G, et al. A case-control study of gastric cancer in Venezuela. Int J Cancer. 2001 Aug 1;93(3):417-23.

19. Hansson LE, Nyrén O, Bergström R, Wolk A, Lindgren A, Baron J, et al. Nutrients and gastric cancer risk. A population-based case-control study in Sweden. Int J Cancer. 1994 Jun 1;57(5):638-44.

20. Chen H, Tucker KL, Graubard BI, Heineman EF, Markin RS, Potischman NA, et al. Nutrient intakes and adenocarcinoma of the esophagus and distal stomach. Nutr Cancer. 2002;42(1):33-40.

21. Ahn YO. Diet and stomach cancer in Korea. Int J Cancer. 1997;Suppl 10:7-9.

22. Sato Y, Nagasaki M, Nakai N, Fushimi T. Physical exercise improves glucose metabolism in lifestyle-related diseases. Exp Biol Med (Maywood). 2003 Nov;228(10):1208-12.

23. Farshchi HR, Taylor MA, Macdonald IA. Beneficial effects of regular meal frequency on thermogenesis, insulin sensitivity and fasting lipid profiles in healthy obese women. Am J Clin Nutr. 2005 Jan;81(2):16-24.

24. Li DG, Gao XH, Guan HW. Relationship between Helicobacter pylori infection other factors and diffuse-and intestinal type stomach carcinomas. Zhonghua Liu Xing Bing Xue Za Zhi. 1995 Oct;16(5):299-302. (In Chinese.)

25. Ji BT, Chow WH, Yang G, McLaughlin JK, Zheng W, Shu XO, et al. Dietary habits and stomach cancer in Shanghai, China. Int J Cancer. 1998 May 29;76(5):659-64

26. Cai L, Zheng ZL, Zhang ZF. Risk factors for the gastric cardia cancer: a casecontrol study in Fujian Province. World J Gastroenterol. 2003 Feb;9(2):214-8.

27. Kaaks R, Tuyns AJ, Haelterman M, Riboli E. Nutrient intake patterns and gastric cancer risk: a case-control study in Belgium. Int J Cancer. 1998 Nov 9;78(4):415-20.

28. Cornée J, Pobel D, Riboli E, Guyader M, Hémon B. A case-control study of gastric cancer and nutritional factors in Marseille, France. Eur J Epidemiol. 1995 Feb;11(1):55-65.

29. Harrison LE, Zhang ZF, Karpeh MS, Sun M, Kurtz RC. The role of dietary factors in the intestinal and diffuse histologic subtypes of gastric adenocarcinoma: a case-control study in the U.S. Cancer. 1997 Sep 15;80(6):1021-8.

30. Henson DE, Dittus C, Younes M, Nguyen H, Albores-Saavedra J. Differential trends in the intestinal and diffuse types of gastric carcinoma in the United States, 1973-2000: increase in the signet ring cell type. Arch Pathol Lab Med. 2004 Jul;128(7):765-70.

31. Augustin LS, Gallus S, Negri E, La Vecchia C. Glycemic index, glycemic load and risk of gastric cancer. Ann Oncol. 2004 Apr;15(4):581-4.

32. Kasim-Karakas SE. Ethnic differences in the insulin resistance syndrome. Am J Clin Nutr. 2000 Mar;71(3):670-1.

33. Schistosomes, liver flukes and Helicobacter pylori. IARC monograph on the evaluation of carcinogenic risks to humans. Vol. 61. Lyon: International Agency for Research on Cancer; 1994.

34. Helicobacter and Cancer Collaborative Group. Gastric cancer and Helicobacter pylori: a combined analysis of 12 case control studies nested within prospective cohorts. Gut. 2001 Sep;49(3):347-53. 